\title{
Cokelet の理論による波の浅水変形
}

\author{
酒 井 哲 郎*. J. A. Battjes**
}

\section{1. まえがき}

最近，定形の有限振幅波理論において新しい展開があ り,とくに Cokelet ${ }^{1)} は$, Longuet-Higgins and Fenton ${ }^{2)}$ 拉よび Longuet-Higgins ${ }^{3)}$ が夫々，孤立波と深海波につ いて，波速，波のエネルギー，エネルギーフラックスな どが波高の増大とともに最高波高に到達する前に極大值 に達することを明らかにしたが，これが任意の水深・波 長比の場合についても成立することを明らかにした，彼 は，新しい級数展開のパラメータを用いて，任意の水深 ・波長比，任意の波形勾配で収束する解を見出した．波 形勾配が大きくなり，水深・波長比が小さくなるほど精 度は減少するものの, 彼の理論は実用上は定形進行波の 厳密解を与えたものと考えることが出来る.ここでは， この理論学波の浅水变形の計算に用い, その結果を従来 の低次の有限振幅波理論を用いた波の浅水变形の理論と 比較して, 従来の理論の精度を検討するとともに, 実験 結果とも比較する.

\section{Cokelet $の$ 理論 $^{1)}$}

Cokelet が扱ったのは, 定形， 2 次元，非回転，周期 的重力波であって, ここでは後の議論に関係する点のみ について述べる. 彼の理論では, すべての水理量は波数 $k$, 流体の密度 $\rho$ および重力加速度 $g$ によって無次元 化されている. 座標系は, $x$ 軸が波の進行方向の水平座 標, $y$ 軸が鉛直上向き座標である. $y=0$ は, 平均水面 とは一致していない. 自由水面は $y=\eta(x, t)$ で与えら れ, 底面は $y=-d$ で与えられるので, 平均水深 $h$ は $h=d+\bar{\eta}$ (ここに，“一”は時間平均を意味する）で与. えられる.この $0 x y$ 座標での $x, y$ 方向の水粒子速度 を夫々 $u, v$, 波速を $c$ で表わす. この座標系は, 波の 谷より下の水中のあらゆる点で $\bar{u}=0$ となるように選ば れており,したがって, 平均の波の質量輸送

$$
I=\overline{\int_{-a}^{\eta} \rho u d y}
$$

は 0 ではない.
複素座標の関数としての複素速度ポテンシャルを, フ 一リェ級数展開した。 その場合, ラプラスの式および底 面および水面での運動学的条件は正確に満足されてい る. 自由表面での力学的条件から，フーリェ級数を決定 する一連の非線型の代数方程式が得られる. これらの非 線型方程式の解として, Cokelet は, 新しいせつ動パラ メー夕

$$
\epsilon^{2}=1-\frac{q_{\text {crest }}^{2} \cdot q_{\text {trough }}^{2}}{c^{4}}
$$

のベき級数展開を用いた，ここで $q_{\text {crest }}, q_{\text {trough }}$ は，波 とともに移動する座標系に怙ける波の峯および谷の自由 表面での水粒子速度である，このパラメータは波の非線 型性の程度を表わすもので, 微小振幅波では 0 , 最高波 で 1 となる. 同じ $\epsilon$ のべきの係数を等しいとおくと係数 を求める式が得られるが，これらの值は電子計算機を用 いて求められた.

Cokelet は, 計算された無次元の種々の水理量（半波 高 $a$, 波速の二乗 $c^{2}$, 質量輸送 $I$, ラディエィション 応力 $S_{x x}$, 位置エネルギー $V$, 運動エネルギー $T$ お よびェネルギーフラックス $F$ ) の值を， $\epsilon^{2}$ と相対水深 $k d$ の関数として表に示している.

\section{3. 浅水変形計算}

\section{（1）仮定}

ここでは古典的な浅水変形の問題，すなわち緩勾配の 不透過な海底面を考え，反射，エネルギー損失を考えな い. 底勾配は十分に小さく，一様水深の理論安使えると する.

\section{（2）座標 系}

上記の状況を考えて, 運動を海底に固定された座標系 から見ることにする. この座標系を $0 x^{\prime} y^{\prime}$ とすると, 波 の峯とエネルギーの保存より, 波の周波数 $\sigma^{\prime}$ とエネル ギーフラックス $F^{\prime}$ は一定となる(ここで“””は $0 x^{\prime} y^{\prime}$ 座標での水理量を意味する)。 また $0 x^{\prime} y^{\prime}$ 座標系での平 均の質量輸送 $I^{\prime}$ は 0 であるが, Cokelet の用いた座標 系 $0 x y$ では質量輸送 $I$ は 0 ではない。このように, $0 x^{\prime} y^{\prime}$ 座標は $0 x y$ 座標に対して,

$$
U=I /(\rho h)
$$


の相対速度を有している.ここでは Cokelet の結果を，

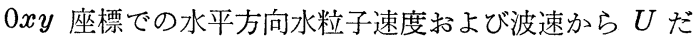
け差し引くことにより， $0 x^{\prime} y^{\prime}$ 座標での量に変換した.

$$
u^{\prime}=u-U, \quad c^{\prime}=c-U
$$

これを, 波の周波数とエネルギーフラックスに対して行 なうと,

$$
\begin{aligned}
\sigma^{\prime} & =\left(c-\frac{I}{\rho h}\right) \cdot k \quad \ldots \ldots \ldots \ldots \ldots \ldots \ldots \ldots \ldots \ldots \\
F^{\prime} & =F-\frac{I}{\rho h}\left(T+V+S_{x x}\right)+\frac{I^{3}}{\rho^{2} h^{2}}
\end{aligned}
$$

が得られる。

\section{(3) 無次元 化}

Cokelet は，すべての水理量を $\rho, k$ および $g$ で無次 元化した.こうして無次元化された量に“〜”をつけて 示すと, エネルギーフラックスに関しては,

$$
\tilde{F}^{\prime}=\frac{k^{5 / 2}}{\rho g^{3 / 2}} \cdot F^{\prime}
$$

が得られる.この無次元化は, 浅水変形の過程では $k$ が 変化するので，ここでの目的には適していない。ここで は，k上りも浅水变形に沶いても变化しない $\sigma^{\prime}$ を用い た方がよい，こうして得られる無次元量を“*”で示す そ,

$$
F^{\prime}=\frac{\sigma^{5}}{\rho g^{4}} F^{\prime}
$$

が得られる。式（7）を式（8）に代入し， $\sigma^{\prime}=c^{\prime} \cdot k, c^{\prime}$ $=(g / k)^{1 / 2} \cdot \tilde{c}^{\prime}$ の関係および式 (3), (4), (6) を用いると, 最終的に次式が得られる。

$$
\begin{aligned}
F^{*}= & \left(\tilde{c}-\frac{\tilde{I}}{\tilde{d}+\tilde{\tilde{\eta}}}\right)^{5} \cdot\left\{\tilde{F}-\frac{\tilde{I}}{\tilde{d}+\tilde{\tilde{\eta}}}\left(\tilde{T}+\tilde{V}+\tilde{S}_{x x}\right)\right. \\
& \left.+\frac{\tilde{I}^{3}}{(\tilde{d}+\tilde{\tilde{\eta}})^{2}}\right\} \quad \ldots \ldots \ldots \ldots \ldots \ldots \ldots \ldots \ldots \ldots \ldots \ldots \ldots \ldots \ldots
\end{aligned}
$$

\section{（4）浅水変形計算の方法}

式 (9)によって， $0 x^{\prime} y^{\prime}$ 座標での，ここでの目的に合 ったように無次元化されたエネルギーフラックスが， $\epsilon^{2}$ と $k d$ の関数として, Cokelet が表にした無次元量によ って完全に与えられる. 周波数 $\sigma^{\prime}$ とエネルギーフラッ クス $F^{\prime}$ は浅水変形の過程において一定であるから， $F^{\prime}$ も一定である（式 (8)). したがって，どこでもその沖で の值 $\stackrel{*}{F_{0}^{\prime}}$ に等しい:

$$
\stackrel{*}{F}^{\prime}\left(\epsilon^{2}, k d\right)=\text { const. }=\stackrel{*}{F_{0}^{\prime}}
$$

浅水変形計算の過程は, 簡単に述べると次の通りであ る. まず，沖波波形勾配 $H_{0} / \lambda_{0}=\pi^{-1} \cdot k_{0} \cdot a_{0}$ が与えられ る( $\lambda$ は波長, “ $0 ”$ は沖波の值を意味する)，この值か ら沖での $\epsilon^{2}$ の值 $\left(\epsilon_{0}^{2}\right)$ が決まり, さらに $F_{0}^{\prime}$ を含めて 沖での諸量が決まる. 与えられた $k d$ の值に対して，式 （10）を $\epsilon^{2}$ について解く（図一1 参照). 求められた $\epsilon^{2}$ の值と $k d$ の值から, この水深での $k a, k \bar{\eta}, k / k_{0}$ 等の 無次元量の值が決まり,したがって波高比 $H / H_{0}=a / a_{0}$

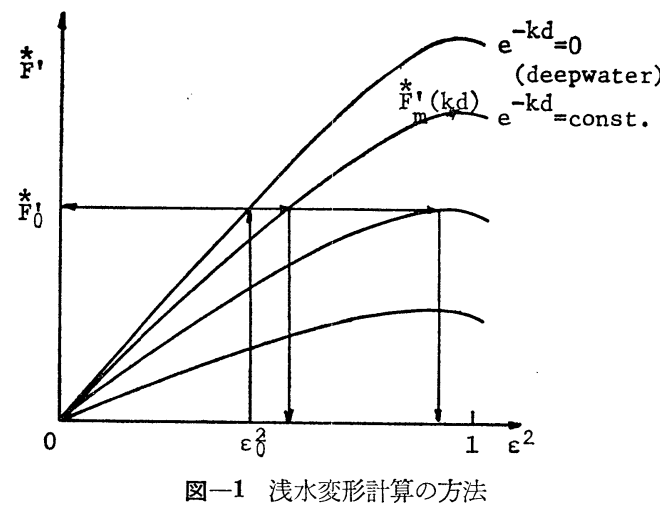

が $H_{0} / \lambda_{0}$ の值をパラメータとして, 相対水深 $h / \lambda_{0}=(d$ $+\bar{\eta}) / \lambda_{0}$ の関数として求められる.

$\epsilon^{2}$ と $k d$ の関数としての $\stackrel{*}{F}^{\prime}$ の変化は，基本的には $\tilde{F}$ と同じ，すなわち相対水深 $k d$ を一定とすると， $F^{\prime}$ は 1 より小さい $\epsilon^{2}$ の值で極大值 $\left({ }_{F}^{\prime}\right)$ をとる (図一1).

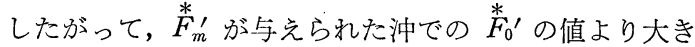
いような $k d$ の值の大きい場合にのみ，式 (10) は解を 有する。 $\stackrel{*}{F}_{m}^{\prime}(k d)$ が ${\stackrel{*}{F_{0}^{\prime}}}^{\prime}$ より小さいような浅い水深で は，波は必要なエネルギーフラックスを維持できない。 $F_{m}^{\prime}=F_{0}^{\prime}$ となる点（この位置は ${\stackrel{*}{F}{ }^{\prime}}^{\prime}$,つまり $H_{0} / \lambda_{0}$ によ って決まる）を，とりあえず砕波点と呼ぶことにする。 浅水変形計算は, この点まで行なった。

Cokelet の表では, $\epsilon^{2}$ の值は 0 から 0.8 までは 0.1 毎に, 0.8 から 1.0 までは 0.01 毎に, また $e^{-k d}$ の 值は 0 から 0.9 まで 0.1 每に, 種々の水理量の值が示 されている.浅水変形計算では 0 から 0.8 までの $\epsilon^{2}$ の 值の間隔は粗すぎるので, 各 $e^{-k a}$ の值に対して, $\epsilon^{2}$ の 0 から 1.0 までの 0.1 毎の 11 種類の值に対する諸 量の值を読みとり，電子計算機を用いて cubic spline に より， $\epsilon^{2}$ の 0 から 0.8 までの 0.01 毎の值を補間し た.こうして得られた值は, $e^{-k d}$ の值の間隔を 0.1 か ら 0.02 にするための補間に用いられた. こうすること によって，浅水変形の曲線が滑らかに描けることにな る、ただし，砕波点近傍ではその変化が急なため， $k d$ に関してさらに細かい間隔での值が必要となった．砕波 点を決定するために, 砕波点近傍では式 (10)を $e^{-k d}$ の $10^{-4}$ 精度で計算した。

\section{4. 結果と考察}

\section{(1) 結果}

計算は, 0.001 から 0.1 までの 11 種類の $H_{0} / \lambda_{0}$ の值 に対して行なった. $H / H_{0}$ の計算值を $h / \lambda_{0}$ の関数とし て図にプロットし，とれらの点を通って滑らかな曲線を 描いた．結果は図一2 の実線で示されている， $H_{0} / \lambda_{0}=0$ の曲線は, 微小振幅波理論による曲線である. Cokelet の理論による曲線の砕波点は，曲線で結ばれている．注 


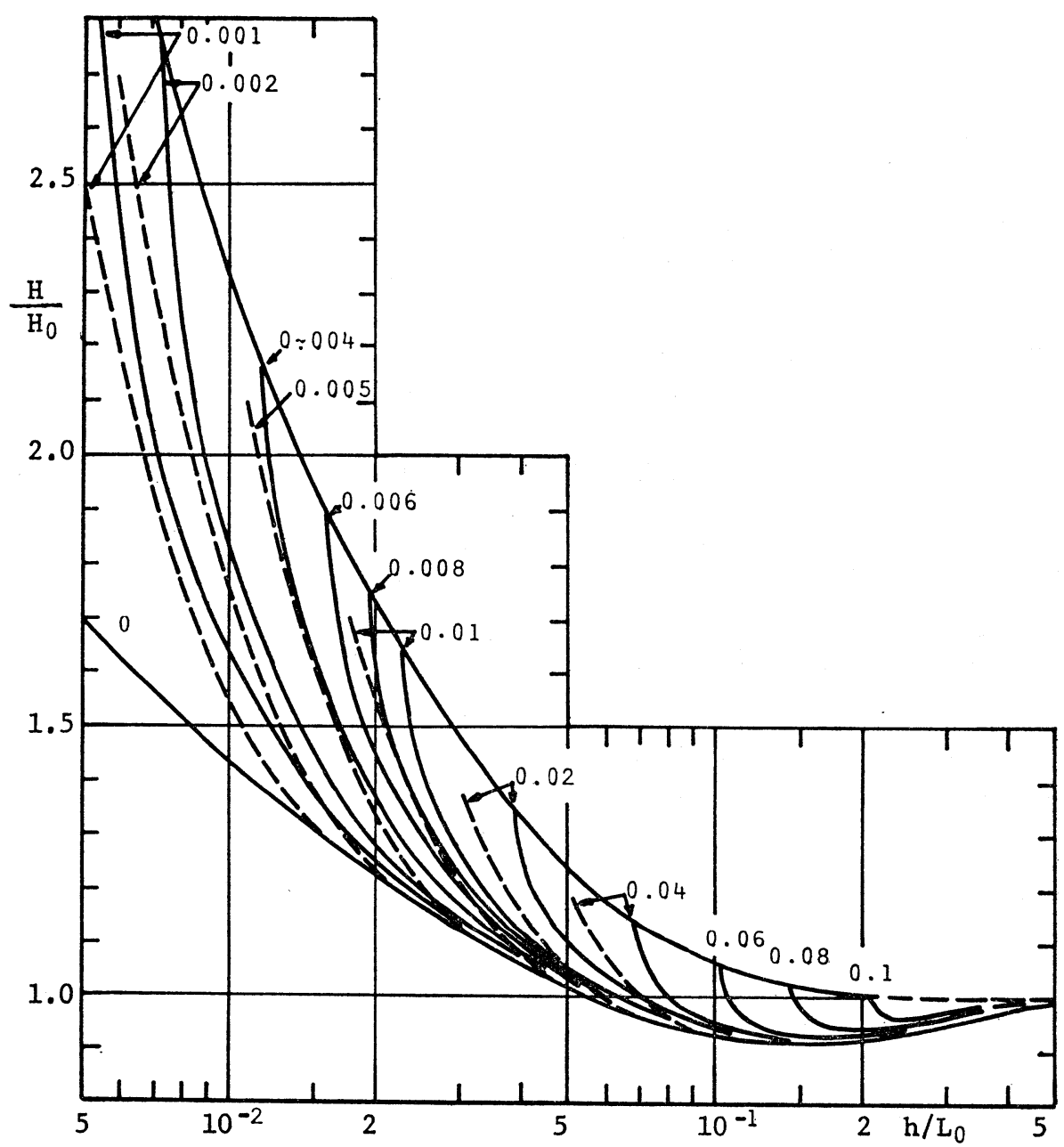

図一2 実線: Cokelet ${ }^{1)}$ の理論による浅水変形曲線, $H_{0} / \lambda_{0}$ の值が示されている, 破線: 港湾の施設の技術上の基準 · 同解説 ${ }^{5)}$ (昭和 54 年運輸省港港湾局監修) 飞示されている首藤4)による浅水变形曲線（文献 5) p. 2-94 の図一 解 4.30 より), $H_{0} / L_{0}$ の值が示されている.

意しなければならないことは， $\lambda_{0}$ が非線型の効果を含え だ沖波波長である点である. 微小振幅波の沖波波長 $L_{0}$ とは異なり, 両者の比を表一 1 に $H_{0} / \lambda_{0}$ の值に対して示 している.

表一1 沖波波表に対する非線空性の効果

\begin{tabular}{l|ccccc}
\hline$H_{0} / \lambda_{0}$ & $0 \leq H_{0} / \lambda_{0} \leq 0.02$ & 0.04 & 0.06 & 0.08 & 0.10 \\
\hline$\lambda_{0} / L_{0}$ & $1 \leq \lambda_{0} / L_{0} \leq 1.01$ & 1.02 & 1.04 & 1.07 & 1.10 \\
\hline
\end{tabular}

$H_{0} / \lambda_{0} \leq 0.04$ の範囲では, $H_{0} / \lambda_{0}$ と $H_{0} / L_{0}$ の相違によ る違いは無視しうる.

\section{（2）砕波点近傍の浅水変形曲線}

砕波点近傍の浅水变形曲線の勾配は, きかめて急であ る.これは，波のエネルギーフラックスが研波点で $\epsilon^{2}$ に関して極大值をとるという事実の当然の結果であ る.このことは，エネルギーフラックスを一定とし
た場合, 砕波点での $\epsilon^{2}$ の值をわずかに変化 $\left(\partial \epsilon^{2}\right)$ させ ても, $k d$ の值は変化しないということを意味している $\left(\delta(k d) /\left.\partial \epsilon^{2}\right|_{F^{\prime}=\text { const. }} ^{*}=0\right) . k d$ が一定の場合, 波形勾配は $\epsilon^{2}$ の単調増加関数であるので, 浅水変形の曲線の勾配 $\partial\left(H / H_{0}\right) /\left.\partial\left(h / \lambda_{0}\right)\right|_{H / \lambda_{0}=\text { const. }}$ は砕波点で無限大となる.こ のことは, 波の諸量の変化がゆるやかであるというここ での浅水変形の計算の仮定に反する. したがって, 砕波 点に近づくにつれて, 浅水変形計算に Cokelet の理論を 用いることに矛盾が生じてくる. 确波点近傍の波の挙動 は, ぞんなに底勾配が緩くても, この理論からは推定で きない。

\section{（3）従来の浅水変形曲線との比較}

従来の低次の有限振幅波理論にもとづく浅水变形曲線 として,Stokes 波の第 3 次近似解にもとづく Le Méhauté and Webb ${ }^{6)}$, Laitone のクノイド波の第 2 近似解の近似 表現であるハイパボリック波を用いた岩垣・酒井7), 
Laitone のクノイド波の第 1 近似解を用いた Svendsen and Brink-Kjaer ${ }^{8}$, 水深の変化の効果を含めた非線型の 浅水理論它解いた首藤 ${ }^{4}$ 小よび Chappelearのクノイド波 の第 2 近似解にもとづく山口・土屋9)の 5 種類の曲線と 比較した. 図一2には, 最近出版された運輸省港湾局監 修の“港湾の施設の技術上の基準 ・同解説”（昭和 54 年 $)^{5)}$ に示されている首藤の曲線との比較を示している. 図からわかるように, 首藤の曲線は, 全体に Cokelet の理論にもとづく曲線と比べて波高比が小さく，とくに 砕波点に近づくにつれてその差が大きくなっている.

Svendsen and Brink-Kjaer の曲線を除く他の理論曲線の いづれについても, この傾向は同じであり, その差はほ とえどないが, 全体的には, 岩垣・酒井执よび山口・土 屋の 2 種類の曲線がもっとも Cokelet の理論による曲線 に近い,ただし，山口・土屋の曲線は, Svendsen and Brink-Kjaer の曲線ほどではないにしても, 相対水深の 大きいところで微小振幅波の值よりも值が小さくなる領 域がある.

すでに（2）で述べたように, Cokelet の理論の砕波点 近傍での適用には問題がある。したがって，たとえ定形 波の厳密解であっても, 波の浅水変形計算にその解を用 いた場合, 必ずしも近似解を用いたものよりもより精度 のよい結果を与えるとはかぎらない，皮肉にも，従来の 低次の有限振幅波理論にもとづく浅水变形曲線に抢いて は上述のような問題はない.なぜならば, これらの低次 の理論ではエネルギーフラックスは波高の単調增加関数 であるからである.

\section{（4）実験值との比較}

浅水变形の実験データとして, Svendsen and BuhrHansen ${ }^{10)}$ のものを理論曲線と比較した。 彼らの実験は 1/35 勾配の斜面上で行なわれ，6ケースの波高変化が示 されている. 実験值とのものは彼らの論文には示されて いないので, 直接彼らからデータを得た. 斜面先端での 波の周期, 波高, 平均水深から, Cokelet の理諭にもと ずく曲線を用いて，沖波波形勾配 $H_{0} / L_{0}$ を計算した。 斜面と水槽側壁での摩擦による波高減衰を見つもるた め, Hunt ${ }^{11)}$ の理論を用いた。この理論では微小振幅で 層流境界層の場合を扱っているが，波高隇衰そのものの 程度が小さいので，この理論で十分と考えられる．理論 による波高 $H$ は, $C_{d} \cdot H_{0} \cdot\left(H / H_{0}\right)_{t}$ として求めた. ここ で, $C_{d}$ は上述の波高減衰率, $\left(H / H_{0}\right)_{t}$ は Cokelet の理 論にもとづく曲線から求めた波高比である。

図一3 は，こうして得られた理論波高と実験値を比べ たもので, 6ケースのうち3ケースを示している $(T:$ 波 の周期). 図から明らかなように，ここに示さなかった 他の 3 ケースも含めて, 実験值と理諭値との一致は, 砕 波点近傍を除いてよい. 砕波点近傍では理論值の方がよ

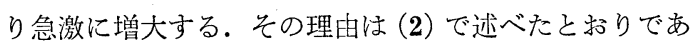
る.なお, Svendsen and Buhr-Hansen は, 彼らの実験 值を Svendsen and Brink-Kjaer ${ }^{8)}$ の浅水変形の曲線と比 ベている. 理論值は砕波点近傍でも実験值とほぼ一致し ている.ただしこれは, 理論曲線の方を, $h / L_{0}=0.1$ で 微小振幅波の理論值と一致するように修正した後の比較 であって，この場合そこでェネルギーフラックスは不連
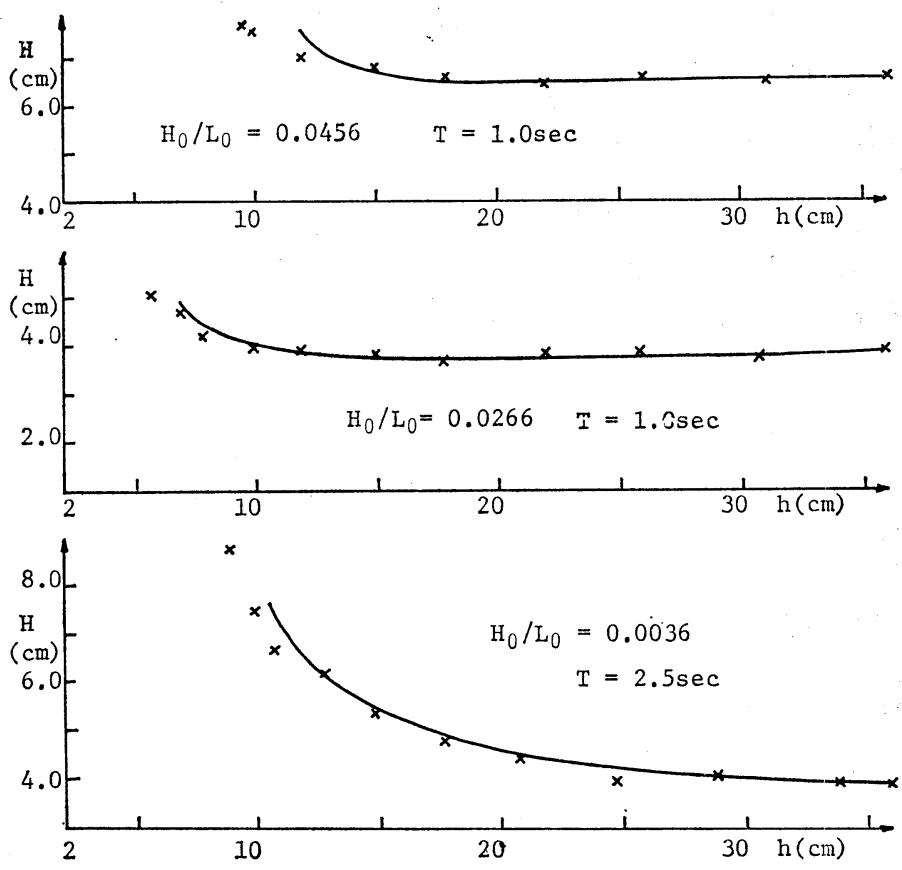

図-3 Svendsen and Buhr-Hansen ${ }^{10)}$ の実験值との比較 


\section{続である.}

ここでは, 従来の浅水変形曲線の精度を量的に検討し ないが, 図一3 の実験值と Cokelet の理論にもとづく曲 線との比較から, Cokelet の理論にもとづく曲線の適用 範囲を決めれば，その範囲内で例えば首藤による曲線の 值が Cokelet の理論にもとづく曲線の值よりどの程度小 さいかは容易にわかる。

\section{5. 謝辞}

この研究に当り, Dr. E. D. Cokelet は彼の理論にお ける種々の水理量の補間值の表を提供してくれた，この 表は, この研究の初期の段階において有益であった. こ こに謝意を表する。 また，実験值のデータ表を提供して くれた Dr. Ib. A. Svendsen に対しても感謝する.な お, この研究は著者の一人, 酒井がデルフト工科大学滞 在中に行なった研究の 1 つで, 電子計算機の利用に関し て, 同大学土木工学科の Mr. S. de Boer に把世話にな った. 最後に著者の 1 人, 酒井は, リサーチフェローシ ップを与えてくれたデルフト工科大学に感謝する.

\section{参 考 文 献}

1) Cokelet, E. D.: Steep gravity waves in water of arbitrary uniform depth, Trans. R. Soc. Lond. 286, A1335, pp. 183 230, 1977.
2) Longuet-Higgins, M. S. and J. D. Fenton: On the mass, momentum, energy and ciculation of a solitary wave, II, Proc. R. Soc. Lond. A340, pp. 471 493, 1974.

3) Longuet-Higgins, M. S.: Integral properties of periodic gravity waves of finite amplitude, Proc. R. Soc. Lond. A342, pp. 157 174, 1975.

4) Shuto, N.: Non-linear long waves in a channel of variable section, Coastal Eng. in Japan, Vol. 17, pp. 1 12, 1974.

5）運輸省港湾局（監修）：港湾の施設の技術上の基準・同解 説, 日本港湾協会, p. 2 94, 1979.

6) Le Méhauté, B. and L. M. Webb: Periodic gravity waves over a gentle slope at a third order approximation, Proc. 9th C.onf. Coastal Eng., pp. $23 \sim 40$, 1964.

7）岩垣雄一・酒井哲郎：有限振幅波の Shoaling について, 第 14 回海岸工学講演会講演集, pp. 1 7, 1967.

8) Svendsen, I. A. and O. Brink-Kjaer: Shoaling of cnoidal waves, Proc. 13th Conf. Coastal Eng., pp. 365 383, 1972.

9）山口正隆·土屋義人：有限振幅波理論に基づく波のShoaling について, 第 22 回海岸工学講演会論文集, pp. 59 63, 1975.

10) Svendsen, I. A. and K. Buhr-Hansen: Deformation up to breaking of periodic waves on a beach, Proc. 15th Conf. Coastal Eng., pp. 477 496, 1976.

11) Hunt, J. N.: Viscous damping of waves over an inclined bed in a channel of finite width, La Houille Blanche, pp. 836 842, 1952. 